\title{
Research on the Integration and Development of Local Tourism Industry Based on Grey Theory
}

\author{
Zhang Junying \\ Tourism College of Qinghai Nationalities University, XiNing 810007, China
}

Keywords: grey theory; GM model; new format; industrial integration

\begin{abstract}
The analysis method in this paper based on grey theory, constructs the tourism industry and commerce, health, study and leisure, emotional and adventure and other industrial integration GM $(1,1)$ model, according to the tourism industry and related industries integration of the original data, the analysis of grey correlation theory. The analysis results show that six related new tourism industry and tourism industry is higher, can promote each other, and the fusion of local tourism industry development strengthens the construction of tourism industry chain, which has certain reference significance to the sustainable development of local tourism industry.
\end{abstract}

\section{Introduction}

With the continuous adjustment of industrial structure, the local third industry is playing an increasingly important role in promoting economic growth, increasing local fiscal revenue and absorbing labor force and employment. Strengthening the third industry has become an important direction for the effective, lasting, healthy and stable development of local economy. With the deepening of the convergence and development of local tourism industry, the concept of sustainable development is deeply rooted in the hearts of the people. The arrival of the era of mass tourism brings new opportunities for the development of tourism industry. Based on the grey theory analysis method, this paper calculates and analyzes the integration development of local tourism industry, aiming to provide some references for the sustainable development of local tourism industry.

\section{Overview of Grey Theory}

System analysis refers to the two or more elements of a certain association that have a specific use of the whole. In the analysis of specific problems, people may only get a small part of information in the analysis object, and can not get all the information. In this state, we use a few data to establish an uncertain and complex problem called grey theory. In short, grey theory refers to a fuzzy system that studies "a small number of known and unknown information", and obtains key information from a small amount of information, so as to achieve understanding and prediction of system behavior and evolution. The grey theory is referred to as the GM $(1,1)$ model, and its description equation is as follows:

$$
x^{(0)}(k)+\alpha z^{(1)}(k)=u
$$

In the formula (1), $x^{(0)}(k)$ is a grey guide value; $\alpha$ is the development coefficient; $z^{(1)}(k)$ is a whitening background value; $u$ is the value of ash action.

The integration of local tourism industry is a new type of tourism service mode. It is upgrading and improvement of traditional tourism industry, and a new way of tourism development. In recent years, this part of the business market is relatively unstable and data is scarce. Linear regression analysis can not solve this problem. The grey system emphasizes the "little data modeling", so this paper uses the grey system to study the problem of local tourism industry integration.

\section{Conditions for the integration of local tourism industry}

Based on the current integration of tourism industry in China, local tourism industry can 
integrate new industries to promote the development of local tourism and meet the needs of tourists in the new era by increasing other industries. The local tourism industry, driven by the market demand and the development of industrial integration, has formed a number of new types of tourism integration. This type of tourism integration because of the difference of function, technology and characteristics of the tourism industry, and the correlation and difference, therefore, the way and method of integration of the tourism industry is also very different, generally divided into resource integration, technology integration, function integration and market integration of four kinds of path. Taking function as a blending path to highlight a certain function of local tourism industry, it brings new opportunities to tourism industry and brings better functional benefits, making the two industries get better development. This paper, taking social function and function as the breakthrough point, carries out the integration of tourism industry with function as the way of communion.

With function as the breakthrough point of tourism industry integration, the new forms of local tourism include three forms of agricultural integration, industrial integration and third industry integration. Among them, agricultural integration includes fruit planting base, scenic area, wetland park and hot spring resort. Industrial integration includes business visits, industrial parks and economic development zones. The third industry integration includes manor, theme park and local cultural characteristics. On the basis of local "eat, live, travel, travel, buy, amuse" and so on, expand the new tourism industry, such as "business, cultivation, learning, leisure, love, strange" and other new forms of tourism. The new integration of local tourism is as shown in Table 1.

Table 1 A view of the new integration of local tourism

\begin{tabular}{|c|c|c|c|}
\hline $\begin{array}{c}\text { Serial } \\
\text { number }\end{array}$ & $\begin{array}{c}\text { Essential } \\
\text { factor }\end{array}$ & Name & Content \\
\hline 1 & merchant & $\begin{array}{c}\text { Business } \\
\text { tourism }\end{array}$ & $\begin{array}{c}\text { Business tourism, such as quality } \\
\text { expansion, conference and exhibition, etc. }\end{array}$ \\
\hline 2 & raise & $\begin{array}{c}\text { Wellness } \\
\text { Tourism }\end{array}$ & $\begin{array}{c}\text { Health tourism, such as sports, health care } \\
\text { and pension }\end{array}$ \\
\hline 3 & learn & $\begin{array}{c}\text { Research } \\
\text { tourism }\end{array}$ & $\begin{array}{c}\text { Folk songs and training, summer camp } \\
\text { and other activities }\end{array}$ \\
\hline 4 & Idle & $\begin{array}{c}\text { Leisure } \\
\text { vacation }\end{array}$ & $\begin{array}{c}\text { Rural leisure, urban leisure and vacation, } \\
\text { etc. }\end{array}$ \\
\hline 5 & feeling & $\begin{array}{c}\text { Emotional } \\
\text { Tourism }\end{array}$ & Wedding and commemorative day travel, \\
etc.
\end{tabular}

As shown in Table 1, there are many forms and categories of function integration for tourism industry. For example, sports tourism, which belongs to elements in the table, is mainly for tourists to improve their health and eliminate fatigue in the process of tourism, so as to achieve physical and mental satisfaction and relaxation. The combination of sports and tourism brings more benefits to tourists and makes the additional functions of tourism integration fully display and play. In addition, sports tourism has also brought new opportunities for development to the sports industry. In addition, in order to function as the theme of tourism integration and business, study and leisure, emotional and adventure etc..

\section{Research on the integration and development of local tourism industry}

grey theory method has been used in this paper, the tourism industry and commerce, health, science, research the close degree of leisure, emotional and adventure industries are calculated and analyzed, and according to the analysis results give recommendations on integration and development of local tourism industry. The degree of integration of local tourism industry and related industries directly reflects the degree of integration, the greater the degree of association and the higher the degree of integration. 


\subsection{Index selection}

In the course of the study of grey theory, tourism industry to increase the value of $Y$, the fusion industry respectively for business, health, study and leisure, emotional and adventure industries. Among them, the total income of the tourism industry (X1), number of travel agencies (X2), the total number of star hotels (X3), business, health, study and leisure, emotional and adventure etc. industrial added value respectively (X4), (X5), (X6), (X7), (X8) and (X9). The data of the tourism industry and related integration industry are shown in Table 2.

Table 2 The original data of the tourism industry and the related integrated industry

\begin{tabular}{|c|c|c|c|c|}
\hline Year & 2014 & 2015 & 2016 & 2017 \\
\hline $\mathrm{Y}$ & 11305 & 15289 & 18631 & 21330 \\
\hline $\mathrm{X}_{1}$ & 15683 & 22500 & 24800 & 29581 \\
\hline $\mathrm{X}_{2}$ & 22781 & 23581 & 22908 & 26054 \\
\hline $\mathrm{X}_{3}$ & 12497 & 13512 & 3219 & 1492 \\
\hline $\mathrm{X}_{4}$ & 3385 & 3780 & 3947 & 4081 \\
\hline $\mathrm{X}_{5}$ & 1691 & 1650 & 1839 & 2076 \\
\hline $\mathrm{X}_{6}$ & 15540 & 16698 & 18486 & 23519 \\
\hline $\mathrm{X}_{7}$ & 40660 & 47597 & 52239 & 56986 \\
\hline $\mathrm{X}_{8}$ & 27920 & 26483 & 25885 & 30193 \\
\hline $\mathrm{X}_{9}$ & 14647 & 12120 & 11830 & 12380 \\
\hline
\end{tabular}

\subsection{Correlation analysis of Grey Theory}

According to the grey theory GM $(1,1)$ model, the calculation is as follows:

(1) Reference sequence $Y(t)$ and comparison sequence $X_{i}(t)(\mathrm{i}=1,2, \ldots 9)$.

(2) According to the different measurement units of the data, the data are processed without Dimensionalization, and the comparability between the factors is enhanced.

(3) Calculate the parameters of each sequence and comparative sequence difference, and calculated the maximum and minimum value of delta min Delta max;

(4) Set the resolution coefficient $\rho$ is 0.5 ;

(5) The correlation coefficient $R_{i}(t)$ is obtained, and the calculation formula is as follows:

$$
R i(t)=\frac{\min |Y(t)-X i(t)|+\rho \max |Y(t)-X i(t)|}{|Y(t)-X i(t)|+\rho \max |Y(t)-X i(t)|}
$$

(6) The result of Correlation degree $r_{i}=\frac{1}{8} \sum_{i=1}^{n} R_{i}(t)(i=1,2,3,4)$ is shown as Table 3.

Table 3 Correlation between tourism industry and related integrated industry

\begin{tabular}{|c|c|c|c|c|c|c|c|c|c|}
\hline Index & $\mathrm{X}_{1}$ & $\mathrm{X}_{2}$ & $\mathrm{X}_{3}$ & $\mathrm{X}_{4}$ & $\mathrm{X}_{5}$ & $\mathrm{X}_{6}$ & $\mathrm{X}_{7}$ & $\mathrm{X}_{8}$ & $\mathrm{X}_{9}$ \\
\hline Correlation degree & 0.842 & 0.682 & 0.663 & 0.849 & 0.781 & 0.826 & 0.898 & 0.682 & 0.661 \\
\hline
\end{tabular}

Can be seen from table 3 , the tourism industry and commerce, health, study and leisure, emotional and adventure and other related industry related degree from large to small order of X7 > $\mathrm{X} 4>\mathrm{X} 6>\mathrm{X} 5>\mathrm{X} 8>\mathrm{X} 9$; among them, business, study and leisure and Tourism Industry Association in more than 0.8 the other; associated with the tourism industry is relatively low, but more than 0.6, which indicated that the fusion of the industry and the tourism industry are very good, can promote the mutual development. In addition, according to the correlation shows that the tourism integration in local tourism, leisure should be appropriate to increase the proportion of fusion fusion had decreased.

\section{Conclusion}

In this paper, in the industrial integration has become the foundation of local tourism industry 
development of new formats, using the gray theory to the tourism industry and commerce, health, science, research the close degree of leisure, emotional and adventure industries are calculated and analyzed. The results indicate that correlation of all six new tourism industry and tourism industry are more than 0.6 , which indicated that the fusion of the industry and the tourism industry are very good, can promote each other, the result of the fusion of local tourism industry development, strengthen the construction of tourism industry chain, has a certain significance.

\section{Acknowledgement}

The work was supported by the the National Social Science Foundation of China with the project number 2015CMZ027 and the project name Study on the Ways and Effects of the Integration of Tourism Industry and Cultural Industry in the Multi-ethnic Tibetan Plateau Region.

\section{References}

[1] Qiu Yanping. A study on the integration and development of tourism industry from the perspective of regional economy [J]. Guangdong Sericulture, Vol. 51 (06), (2017), p.49, 51.

[2] Luo Xing. Study on the integration model of regional tourism industry in Chongqing under the background of global tourism [D]. Chongqing Normal University, (2017).

[3] Tian Li, Zhang Pengyang. Literature review and research framework for the integration of tourism industry, construction of [J]. Technoeconomics \& Management Research, No.09, (2016) p.119-123.

[4] He Jinqi. Research on the integration mechanism of urban performing and tourism industry [D]. Shenyang Normal University, (2016).

[5] Jiang Xueping. Study on the optimization of tourism industrial structure in Hunan province [D]. Xiangtan University, (2016).

[6] Liu Xiangheng. An Empirical Study on the integration of China's tourism industry [J]. Contemporary Economic Management, Vol. 38 (03), (2016), p,55-61.

[7] Feng Chao. Study on the degree of integration of cultural industry and tourism industry [D]. Xi'an International Studies University, (2014).

[8] Liu Haibin. Research on the upgrading and optimization of the ecological system structure of tourism industry based on industrial integration [D]. Ocean University of China, (2014).

[9] Liao Hui. Construction and Empirical Study of the economic growth effect model of tourism industry of local city, [D]. Hunan University of Science and Technology, (2014).

[10] Su Yue. Research on the development of cultural tourism industry in Guilin based on the perspective of integration [D]. Guangxi Normal University, (2014).

[11] Qiu Xiaoya. The perspective of industry convergence [D]. study on the tourist development of new formats based on the Henan University, (2014).

[12] Zhou Ye. Based on the theory of grey system, Jiangxi cultural industry and tourism industry coupling development [J]. Jiangxi Social Science, Vol. 34 (03), (2014), p.41-45.

[13] Wang Dapeng, Zou Guangqi. Research on the development of tourism industry in Hebei Province Based on grey system theory [J]. China collective economy, Vol. 04, (2014), p.62-64.

[14] Xu Chunhong. An Empirical Study on the economic development of urban tourism industry based on Grey System Theory -- Taking Ningbo as an example [J]. Tourism research, Vol.6 (01), (2014), p.82-87.

[15] Zhong Sheng. Research on the integration and development of tourism industry and cultural industry based on cultural image [D]. Wuhan University, (2013). 
[16] Liu Junqing. The realization mechanism and path of China's tourism industry integration [J]. Economic Forum, Vol.11, (2012), p.113-115.

[17] Ji Sheng. Research on the competitiveness of coastal tourism industry in Shandong Province Based on grey system theory [D]. China Oceanic University, (2012).

[18] Gao Lingjiang, Xia Jiechang. The dynamic mechanism, path and policy choice of the integration of China's tourism industry [J]. Journal of Capital University of Economics and Business, Vol.14 (02), (2012), p.52-57. 